\title{
PODEJŚCIA BADAWCZE W ZARZADZANIU PROJEKTAMI - GENEZA I EWOLUCJA
}

https://doi.org/10.33141/po.2019.03.01

Michał Trocki
Przegląd Organizacji, Nr 3 (950), 2019, ss. 3-9 www.przegladorganizacji.pl @Towarzystwo Naukowe Organizacji i Kierownictwa (TNOiK)

\section{Wprowadzenie}

$\mathbf{H}$ istoria zarządzania projektami sięga głęboko w przeszłość. Projekty towarzyszą rozwojowi cywilizacji od jej zarania, co więcej, można bez przesady stwierdzić, że to właśnie projekty tworzyły cywilizacje (Chiu, 2010).

Rozwój zarząadzania projektami jako nowoczesnej dziedziny wiedzy praktycznej wiąże się z okresem drugiej wojny światowej i z następującym po niej okresem wyścigu zbrojeń w trakcie tzw. „zimnej wojny”. Zrealizowane w tym okresie liczne projekty wojskowe stworzyły podstawy nowoczesnej wiedzy zarządzania projektami. Po ograniczeniu wyścigu zbrojeń rolę tę przejęly projekty kosmiczne oraz wielkie projekty cywilne (Seymour, Hussein, 2014).

Badania obejmujące okres od początku XX w. do czasów współczesnych wykazały istnienie wyraźnej tendencji wzrostu udziału i znaczenia projektów w gospodarce, w organizacjach i w życiu jednostek, określanej mianem projektyzacji (projectification) (Nieto-Rodriguez, 2012; Packendorff, Lindgren, 2014; Lundin, 2016).

Zarządzanie projektami jest dzisiaj rozwiniętą dziedziną zarządzania, znajdującą zastosowanie we wszystkich obszarach aktywności ludzkiej, o wyraźnie ukształtowanej odrębności:

- przedmiotu zainteresowania (projekty),

- podstaw teoretycznych (podejście systemowe, procesowe itd.),

- podstaw metodycznych (specjalne metody i techniki),

- literatury przedmiotu (monografie i podręczniki),

- edukacyjnej (kierunki studiów i specjalistyczne szkolenia),

- czasopiśmienniczej (własne czasopisma fachowe i naukowe),

- instytucjonalnej (instytucje naukowe i stowarzyszenia zawodowe),
- profesjonalnej (specjalizacje zawodowe, certyfikacje kwalifikacji zawodowych).

Wzrost udziału i znaczenia projektów wywołał zapotrzebowanie na zweryfikowaną naukowo, profesjonalną wiedzę z zakresu zarządzania projektami. Dało to impuls do rozwoju zarządzania projektami jako dziedziny naukowej. Dorobek będący wynikiem tego rozwoju osiągnął już stan umożliwiający refleksję nad genezą i ewolucją podstaw metodologicznych, podejść badawczych i paradygmatów stosowanych $\mathrm{w}$ badaniach zarządzania projektami. W artykule przedstawiono wyniki takiej refleksji opartej na analizie koncepcji metodologicznych - ogólnych i z zakresu nauk o zarządzaniu - oraz na analizie literatury przedmiotu.

\section{Postępowanie badawcze}

$\mathbf{P}$ rzystępując do badania określonego fragmentu rzeczywistości, badacze powinni kierować się racjonalnym i uporządkowanym sposobem postępowania, swoistym modus operandi. W praktyce stosowane są różne sposoby postępowania występujące pod różnymi określeniami: filozofii badawczych, koncepcji badawczych/teoretycznych, perspektyw badawczych, podejść badawczych, paradygmatów, modeli badawczych itd.

Świadomość stosowanego $\mathrm{w}$ danej dziedzinie nauki postępowania badawczego jest niezbędna dla prawidłowego zrozumienia istniejącego dorobku naukowego tej dziedziny, jej deficytów naukowych i kierunków rozwoju. Ogólny schemat takiego postępowania przedstawiony jest na rysunku 1.

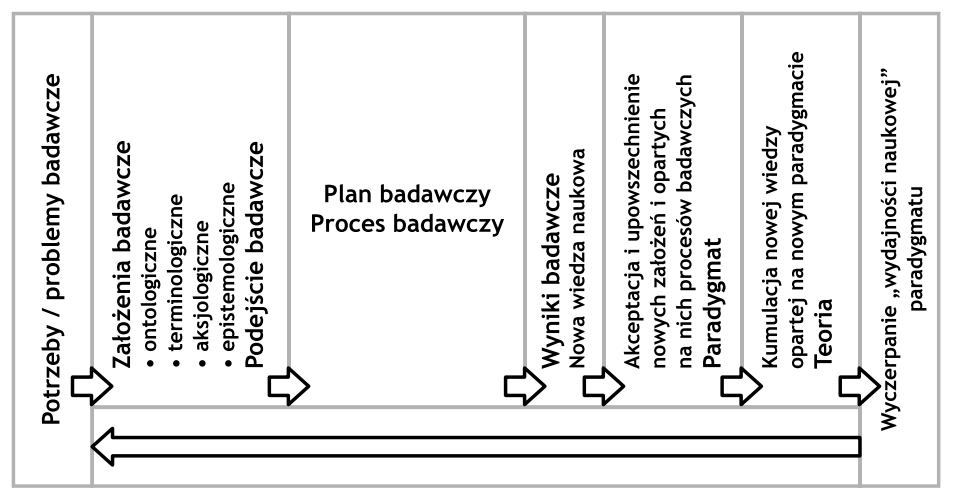

Rys. 1. Tryb postępowania badawczego Źródto: opracowanie wtasne 
Postępowanie badawcze rozpoczyna się od pojawienia się potrzeby badawczej, czyli potrzeby uzyskania nowej wiedzy o rzeczywistości. Mamy tu na myśli wiedzę naukową, czyli wiedzę posiadającą cechy ogólności, oryginalności, obiektywności, zasadności, komunikatywności, uporządkowania i użyteczności (Stachak, 1997 s. 16-21). Potrzeba badawcza wyznacza problem badawczy, czyli różnicę pomiędzy pożądanym a istniejącym stanem wiedzy, czyli deficyt wiedzy, który chcemy zlikwidować. Podejmując postępowanie badawcze zmierzające do likwidacji określonego deficytu wiedzy, przyjąć musimy zestaw podstawowych założeń badawczych dotyczących odpowiedzi na następujące pytania:

- co chcemy badać?/co ma być przedmiotem badań? (założenia ontologiczne),

- jak nazywać składowe przedmiotu badań? (założenia terminologiczne),

- jakie są wartości i cele badań? (założenia aksjologiczne), - jak/za pomocą jakich metod badać? (założenia epistemologiczne) (Krzyżanowski, 1985, s. 91-93).

Założenia ontologiczne określają zakres rzeczywistości interesujący badacza poprzez określenie jej elementów - rzeczy, procesów, zdarzeń - i relacji pomiędzy nimi. „Czynnik ontologiczny wpływa na ogólne pojmowanie rzeczywistości przez badacza” (Bombała, 2018 s. 13), „wpływa na to, co badacz uważa za rzeczywiste lub wyobrażone, prawdziwe lub fałszywe, czy świadome versus nieświadome" (Strang, 2015 s. 21). Założenia terminologiczne określają język, za pomocą którego może być opisywana badana rzeczywistość. Założenia aksjologiczne określają wartości i cele, którym służyć ma badanie oraz wynikające $\mathrm{z}$ nich kryteria oceny wyników badania. Założenia epistemologiczne określają natomiast zasady, sposoby, procesy i metody badań, ocenę ich poprawności, skuteczności i wartości poznawczej. Kompletny i spójny zestaw założeń badawczych określa podejście badawcze.

Problemy badawcze rozwiązywane powinny być w oparciu o spójne podejścia badawcze. Podejścia akceptowane i stosowane przez szerszą grupę badaczy stanowią podstawę paradygmatów danej dziedziny nauki. Podejścia badawcze i tworzące je założenia badawcze nie są niezmienne i nie są dane raz na zawsze; podlegają modyfikacjom lub są porzucane w przypadku, gdy przestają być „wydajne naukowo”, tzn. gdy nie przyczyniają się $\mathrm{w}$ dostatecznym stopniu do tworzenia oryginalnej wiedzy naukowej. W takiej sytuacji formułowane są nowe założenia badawcze, określające nowe podejście naukowe prowadzące do nowego paradygmatu naukowego.

Badania realizowane są $\mathrm{w}$ oparciu o plan badawczy (research design), „kierujący badaczem na różnych etapach badania - zbierania, analizowania i interpretowania danych - i pomagający mu rozwiązać problemy badawcze" (Frankfort-Nachmias, Nachmias, 2001, s. 114 i 139). Plan badawczy realizowany może być według różnych schematów postępowania obejmujących zestaw procesów badawczych o różnej treści i strukturze (Frankfort-Nachmias, Nachmias, 2001; Apanowicz, 2005; Tharenau i in., 2007; Bryman, Bell, 2007).
W wyniku realizacji procesów badawczych uzyskiwane zostają wyniki naukowe zawierające nową wiedzę stanowiącą rozwiązanie problemu badawczego.

Jeśli podejście badawcze oparte na określonych założeniach badawczych, realizowane za pomocą właściwego planu badawczego i procesów badawczych, uzyska szeroką akceptację i upowszechni się, wówczas można mówić o powstaniu nowego paradygmaty naukowego. Kumulacja nowej wiedzy opartej na tym paradygmacie doprowadzić może do nowej teorii dotyczącej badanej rzeczywistości, rozumianej jako „zespół twierdzeń podstawowych dotyczących jakiejś grupy zjawisk i wyjaśniających je” (Pszczołowski, 1978, s. 246).

Jeśli z czasem pojawią się nowe potrzeby i problemy badawcze niemożliwe do realizacji w ramach tego paradygmatu, czyli nastąpi wyczerpanie jego „wydajności naukowej”, wówczas może mieć miejsce poszukiwanie nowego podejścia badawczego opartego na nowych założeniach badawczych, otwierające drogę do powstania kolejnego paradygmatu naukowego.

W nawiązaniu do powyższego wyjaśnienia wymaga pojęcie paradygmatu. D.L. Morgan wskazuje, że paradygmat może być interpretowany na czterech różnych poziomach rozważań:

- na pierwszym i najwyższym poziomie ogólności paradygmat oznacza światopogląd, czyli sposób myślenia o świecie,

- na drugim poziomie paradygmat oznacza postawę epistemologiczną, czyli system przekonań badacza „o naturze wiedzy wpływającej na pytanie i pytania, które należy zadać",

- na trzecim poziomie paradygmat oznacza wspólne przekonania, które konstytuują/stanowią społeczność badawczą pewnego obszaru badawczego w oparciu o „konsensus dotyczący najbardziej znaczących pytań i najbardziej odpowiednich podejść do badań, aby odpowiedzieć na te pytania”,

- na czwartym i najbardziej szczegółowym poziomie paradygmaty są szczególnym modelem, przykładem na to, jak prowadzone są badania w pewnej dziedzinie (Morgan, 2007, s. 48-76).

Przedmiotem rozważań zawartych w niniejszym artykule jest paradygmat czwartego poziomu, stanowiący istotę podejścia badawczego. Spośród licznych jego definicji najczęściej przywoływana jest definicja T. Kuhna (2011, s. 53), określająca paradygmaty jako „ogólne, oryginalne i atrakcyjne przekonania teoretyczne, założenia i teorie naukowe, powszechnie uznawane $\mathrm{w}$ danym czasie, wokół których powstaje uznana tradycja badawcza, obejmująca kierunki badań, szkoły naukowe itd.” Dwa aspekty tej definicji mają szczególne znaczenie dla jej interpretacji: pierwszy, metodyczny, dotyczący rodzaju i sposobu pozyskiwania wiedzy naukowej, i drugi, naukoznawczy/socjologiczny, dotyczący jej rozpowszechnienia. Z punktu widzenia rozważań zawartych $\mathrm{w}$ niniejszym artykule istotny jest przede wszystkim aspekt metodyczny, czyli treść metodyczna paradygmatu. Obejmuje ona, zgodnie z szeroko podzielanymi poglądami, „minimum założeń obejmujących: naturę rzeczywistości organizacyjnej (ontologia), sposób jej poznawania (episte- 
mologia i metodologia), kryteria prawdy naukowej (...), stosunek do wartości (aksjologia)" (Sułkowski, 2016, s. 136).

Tak interpretowany paradygmat powinien charakteryzować się:

- eksplikatywnością, czyli ma służyć opisowi, wyjaśnieniu danego przedmiotu sprawy,

- temporalnością, czyli ma odnosić się do konkretnego czasu, co oznacza, że w innym czasie może już nie obowiązywać,

- progresywnością, czyli twórczym poszukiwaniem nowych, lepszych rozwiązań,

- metodycznością, czyli konsekwentnym postępowaniem według pewnej metody lub jakiegoś planu,
- strukturalnością, czyli kompletnym i spójnym zestawem ograniczonej liczby elementów,

- skutecznością, czyli zdolnością do tworzenia oryginalnej wiedzy naukowej (Sułkowski, 2016, s. 136).

\section{Podejścia badawcze w zarządzaniu projektami}

D efleksja naukowa dotycząca zarządzania projektami poDawiła się na przełomie XIX i XX wieku wraz z rozwojem tzw. naukowego zarządzania (Klincewicz, 2016, s. 57-67). Dwaj przedstawiciele tego kierunku, Polak K. Adamiecki i Amerykanin H.L. Gantt, uważani są za prekursorów nauki

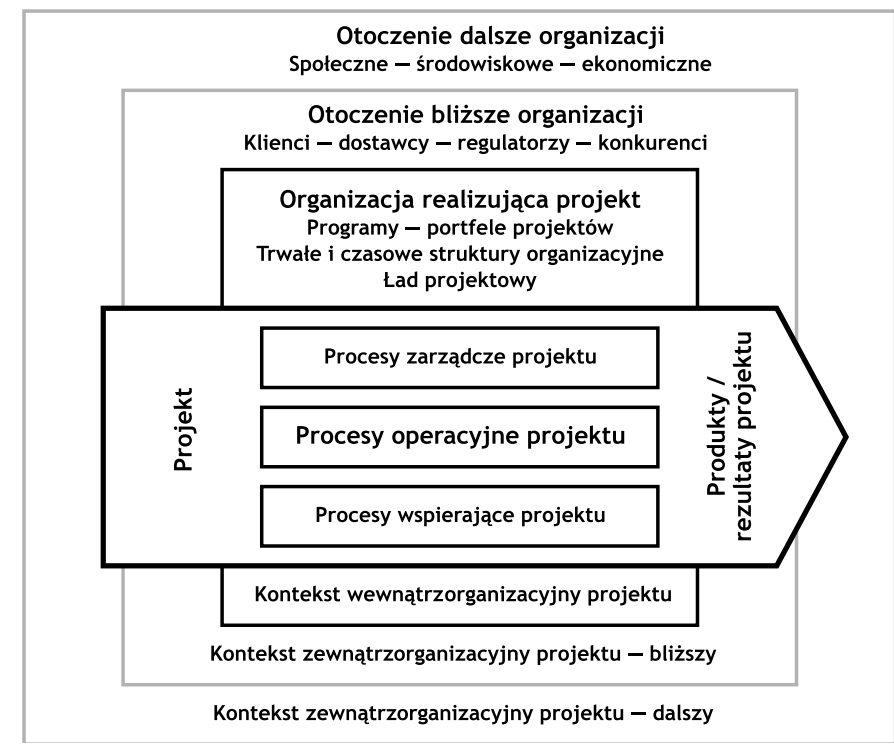

Rys. 2. „Rzeczywistość” zarządzania projektami

Źródto: opracowanie wtasne

Tabela 1. Zakres przedmiotowy podejść badawczych w zarządzaniu projektami

\begin{tabular}{|c|c|c|c|c|}
\hline $\begin{array}{c}\text { Podejścia } \\
\text { Zakres / zjawiska / pojęcia }\end{array}$ & $\begin{array}{l}\text { Podejście } \\
\text { operacyjne }\end{array}$ & $\begin{array}{l}\text { Podejście } \\
\text { procesowe }\end{array}$ & $\begin{array}{l}\text { Podejście } \\
\text { organizacyjne }\end{array}$ & $\begin{array}{c}\text { Podejście } \\
\text { zrównoważone }\end{array}$ \\
\hline Procesy operacyjne & $\mathrm{x}$ & $\mathrm{x}$ & $\mathrm{x}$ & $\mathrm{x}$ \\
\hline Procesy wspomagające & & $\mathrm{x}$ & $\mathrm{x}$ & $\mathrm{x}$ \\
\hline Procesy zarządcze & & $\mathrm{x}$ & $\mathrm{x}$ & $\mathrm{x}$ \\
\hline Programy & $\mathrm{x}$ & $\mathrm{x}$ & $\mathrm{x}$ & $\mathrm{x}$ \\
\hline Portfel projektów & & & $\mathrm{x}$ & $\mathrm{x}$ \\
\hline Angażowanie interesariuszy & & $\mathrm{x}$ & $\mathrm{x}$ & $\mathrm{x}$ \\
\hline Organizacja projektowa & & & $\mathrm{x}$ & $\mathrm{x}$ \\
\hline PMO Biuro zarządzania projektami & & & $\mathrm{x}$ & $\mathrm{x}$ \\
\hline Dojrzałość projektowa & & & $\mathrm{x}$ & $\mathrm{x}$ \\
\hline Ład projektowy & & & $\mathrm{x}$ & $\mathrm{x}$ \\
\hline Otoczenie dalsze - środowisko & & & & $\mathrm{x}$ \\
\hline Otoczenie dalsze - społeczeństwo & & & & $\mathrm{x}$ \\
\hline Otoczenie dalsze - gospodarka & & & & $\mathrm{x}$ \\
\hline
\end{tabular}

Źródto: opracowanie wtasne 
Tabela 2. Podejścia badawcze do zarządzania projektami i ich charakterystyka

\begin{tabular}{|c|c|c|}
\hline Kryteria $\quad$ Podejścia & Podejście operacyjne & Podejście procesowe \\
\hline Inspiracje praktyczne & $\begin{array}{l}\text { Projektyzacja: wzrost znaczenia i udziału projektów, } \\
\text { wymagania skuteczności i efektywności procesów } \\
\text { pracy, wzrost złożoności projektów, rozwój technologii } \\
\text { informatycznych }\end{array}$ & $\begin{array}{l}\text { Projektyzacja: wzrost wymagań dotyczących jakości } \\
\text { rezultatów projektów, ich skuteczności i efektywności, } \\
\text { rozszerzenie kręgu uczestników działalności projektowej, } \\
\text { profesjonalizacja i instytucjonalizacja zarządzania } \\
\text { projektami }\end{array}$ \\
\hline Inspiracje teoretyczne & $\begin{array}{l}\text { Ekonomia, naukowe zarządzanie, badania operacyjne, } \\
\text { teoria ograniczeń }\end{array}$ & $\begin{array}{l}\text { Podejście procesowe, teoria organizacji, cybernetyka, } \\
\text { teoria systemów, kompleksowe zarządzanie przez jakość, } \\
\text { ciągłe doskonalenie procesów, reenginering }\end{array}$ \\
\hline Założenia ontologiczne & Procesy operacyjne/wykonawcze projektu & $\begin{array}{l}\text { Kompletny i spójny zestaw procesów projektowych } \\
\text { obejmujący zarówno procesy operacyjne/wykonawcze, jak } \\
\text { też wspomagające i zarządcze }\end{array}$ \\
\hline Założenia aksjologiczne & $\begin{array}{l}\text { Skuteczność rezultatu projektu, co do zakresu, jakości, } \\
\text { terminu, kosztów, w horyzoncie krótkoterminowym, czyli } \\
\text { na zakończenie projektu }\end{array}$ & $\begin{array}{l}\text { Skuteczność i użyteczność rezultatów/produktów projektu } \\
\text { i efektywność procesów jego realizacji }\end{array}$ \\
\hline $\begin{array}{l}\text { Założenia } \\
\text { terminologiczne }\end{array}$ & $\begin{array}{l}\text { Projekt, przedsięwzięcie, czynności, zdarzenia, sieć } \\
\text { czynności, czasy trwania, terminy, zasoby, rezerwy, ścieżka } \\
\text { krytyczna }\end{array}$ & $\begin{array}{l}\text { Jak w podejściu operacyjnym oraz: cykl życia projektu: } \\
\text { jego fazy, etapy i procesy, obszary tematyczne projektu } \\
\text { (zakres, integracja, interesariusze, ryzyka, komunikacja, } \\
\text { koszty, budżet), środowiska projektowe, produkty projektu }\end{array}$ \\
\hline Definicja projektu & $\begin{array}{l}\text { Projekt: złożony proces, czyli ciąg działań zmierzających } \\
\text { do osiągniecia założonego rezultatu/produktu }\end{array}$ & $\begin{array}{l}\text { Projekt: unikatowy zestaw procesów składających się ze } \\
\text { skoordynowanych i kontrolowanych działan z datami } \\
\text { rozpoczęcia i zakończenia, realizowanymi w celu } \\
\text { osiągnięcia celów projektu (PMI) }\end{array}$ \\
\hline $\begin{array}{l}\text { Założenia } \\
\text { epistemologiczne }\end{array}$ & $\begin{array}{l}\text { Badanie i usprawnianie/optymalizacja przebiegu projektu, } \\
\text { metody racjonalizacji, teoria grafów, analiza/optymalizacja } \\
\text { sieciowa, metody stochastyczne, drzewa decyzyjne }\end{array}$ & $\begin{array}{l}\text { Badanie i usprawnianie realizacji projektu w pełnym cyklu } \\
\text { życia - w wymiarze strukturalnym, czasowym, zasobowym } \\
\text { - oraz we wszystkich obszarach tematycznych }\end{array}$ \\
\hline Upowszechnienie & $1960-$ & $1980-$ \\
\hline $\begin{array}{l}\text { Wkład do rozwoju } \\
\text { zarządzania projektami }\end{array}$ & $\begin{array}{l}\text { Metody wykreślne, kamienie milowe, metoda linii } \\
\text { równowagi, metody drzewa istotności, metoda wartości } \\
\text { wypracowanej, normy planowania sieciowego, aplikacje } \\
\text { wspomagająca zarządzanie projektami, łańcuch krytyczny }\end{array}$ & $\begin{array}{l}\text { Stowarzyszenia fachowe krajowe i międzynarodowe, } \\
\text { kategoryzacja projektów, metodyki, standardy i normy } \\
\text { zarządzania projektami, informatyczne wspomaganie } \\
\text { zarządzania projektami, czasopisma fachowe/naukowe, } \\
\text { systemy ramowe kompetencji i certyfikacja }\end{array}$ \\
\hline Perspektywy rozwoju & $\begin{array}{l}\text { Doskonalenie istniejących rozwiązań z zakresu zarządzania } \\
\text { procesami podstawowymi/wytwórczymi projektów }\end{array}$ & $\begin{array}{l}\text { Doskonalenie i rozwój metodyk i standardów zarządzania } \\
\text { projektami, dopasowywanie metodyk do wymagań konkret- } \\
\text { nej organizacji }\end{array}$ \\
\hline
\end{tabular}

Źródto: opracowanie wtasne

o zarządzaniu projektami. Jej dalszy rozwój kształtowały koncepcje teoretyczne nauk o zarządzaniu, takie jak np.: teoria organizacji, badania operacyjne, cybernetyka i teoria systemów, podejście procesowe i sytuacyjne, teoria interesariuszy (Klincewicz, 2016). Aktualnie nauka o zarządzaniu projektami uznawana jest za subdyscyplinę nauk o zarządzaniu (Cyfert i in., 2014; Abbasi, Jaafari, 2018).

Przeniesienie ogólnych rozważań metodologicznych do zarządzania projektami wymaga przedstawienia zakresu „rzeczywistości” zarządzania projektami (Blackburn, 2004 , s. 355). Obejmuje ona zgodnie z szerokim konsensusem środowisk zarządzania projektami (ISO, 2012):

- procesy realizacji projektu: operacyjne, wspomagające i zarządcze,
- produkty/rezultaty realizacji projektu,

- programy i portfele projektów,

- trwałe i czasowe struktury organizacji realizującej projekt,

- ład projektowy organizacji (project governance),

- interesariuszy zewnętrznych organizacji i projektu: klientów, dostawców, regulatorów, konkurentów,

- otoczenia dalsze organizacji: środowiskowe, społeczne, ekonomiczne (rys. 2).

Badania w obszarze zarządzania projektami mogą się odnosić do różnego zakresu tej „rzeczywistości” projektowej, tworząc w ten sposób różne podejścia badawcze. Przyjmując jako podstawowe założenia ontologiczne, czyli dotyczące zakresu badanej rzeczywistości, wyróżnić można następujące podejścia badawcze do zarządzania 
Projektyzacja: wzrost wymagań wpływu projektów na efektywność organizacji, wzrost ryzyka projektów, realizacja programów i portfeli projektów, potrzeba oburęczności organizacji, wpływ interesariuszy na projekty, potrzeba adekwatnych form organizacji projektowej, biura zarządzania projektami, adaptacyjne / zwinne zarządzanie projektami, ład projektowy

Teorie organizacji i podejmowania decyzji, cybernetyka, teoria systemów, podejście sytuacyjne, dopasowanie organizacyjne, organizacje czasowe, teoria interesariuszy, metody portfelowe, zarządzanie ryzykiem, zarządzanie wartością, zarządzanie wiedzą, zarządzanie zmianami

System zarządzania obejmujący zarządzanie pojedynczymi projektami, programami i portfelami oraz rozwiązania organizacyjne umożliwiające ich skuteczna i efektywną realizację

Wartość rezultatów projektu dla organizacji

\section{Podejście \\ organizacyjne}

Podejście

zrównoważone

Projektyzacja: świat VUCA, megaprojekty, projekty międzynarodowe, wielokulturowe i międzyorganizacyjne, rozproszone zespoły projektowe, zwinność zarządzania na poziomie organizacji, negatywne skutki środowiskowe, społeczne i ekonomiczne projektów, cyfryzacja / digitalizacja

Teoria złożoności, sieci międzyorganizacyjne, zarządzanie zmianą, zarządzanie kosztami całkowitymi TCM, teoria interesariuszy, teoria komunikacji, zrównoważony rozwój, społeczna odpowiedzialność biznesu

Całość zjawisk związanych z realizacją projektu: procesy i struktury projektowe, ich kontekst wewnątrz - i zewnątrz-organizacyjny, odniesionych do horyzontu krótko-, średnio i długookresowego

Zrównoważony rozwój, spełnienie oczekiwań interesariuszy projektu

Jak w podejściu operacyjnym, procesowym i organizacyjnym oraz: otoczenie dalsze projektu, czynniki środowiskowe, społeczne i ekonomiczne, zrównoważony rozwój, społeczna odpowiedzialność projektów, uczestnicy działalności projektowej, organizacja projektowa, zespół projektowy, role i kompetencje projektowe, uprawnienia i odpowiedzialności

Projekt: tymczasowa organizacja powołana w celu wytworzenia - w przyjętym czasie oraz przy wykorzystaniu uprzednio określonych zasobów - niepowtarzalnych, a wcześniej określonych wyników czy rezultatu" (PRINCE2)

Badanie i usprawnianie systemu organizacyjnego realizacji projektów

$2000-$

Metodyki, standardy i normy zarządzania programami i portfelami, ewaluacja projektów, systemy certyfikacji, controlling projektowy, modele dojrzałości projektowej organizacji, modele referencyjne organizacji projektowej i biur zarządzania projektami, ramowe zestawy kompetencji, metody zwinne, zasady ładu projektowego

Dalsza integracja zarządzania projektami z zarządzaniem organizacją (zwłaszcza z zarządzaniem strategicznym i operacyjnym) w kierunku tworzenia ładu projektowego organizacji
Badanie i usprawnianie realizacji projektu z uwzględnieniem wymagań i ograniczeń interesariuszy, realizacja postulatów społecznej odpowiedzialności projektów

$2010-$

Projekt: czasowa organizacja utworzona w celu dostarczania produktów o zrównoważonym oddziaływaniu środowiskowym, społecznym i ekonomicznym

Model CIFTER, metodyki pomocowe, metodyki i standardy zarząazania wielkimi projektami, standardy zrównoważonego społecznie odpowiedzialnego zarzadzania projektami, nowoczesne rozwiązania informatyczne

Dalszy rozwój zrównoważonego, społecznie odpowiedzialnego zarządzania projektami projektami: podejście operacyjne, podejście procesowe, podejście organizacyjne i podejście zrównoważone.

Zakres „rzeczywistości” zarządzania projektami objęty tymi podejściami przedstawia tabela 1 .

Charakterystyka ogólna podejść:

- podejście operacyjne ogranicza się do procesów wykonawczych/wytwórczych i traktuje projekty w sposób w znacznym stopniu izolowany od ich otoczenia,

- podejście procesowe obejmuje wszystkie procesy realizacji projektu - wykonawcze/wytwórcze, wspierające i zarządcze oraz uwzględnia ich wzajemne relacje,

- podejście organizacyjne/instytucjonalne wiąże procesy realizacji projektów z procesami zarządzania organizacją macierzystą,
- podejście zrównoważone wiąże projekty z otoczeniem bliższym i dalszym, lokalnym i globalnym i określa wynikające $z$ tego zobowiązania.

Charakterystyka poszczególnych podejść przedstawiona jest w tabeli 2 w odniesieniu do: inspiracji praktycznych, inspiracji teoretycznych, założeń ontologicznych, założeń aksjologicznych, założeń terminologicznych, założeń epistemologicznych, okresu upowszechnienia, wkładu do rozwoju zarządzania projektami, perspektyw rozwoju.

Podejścia nie są przedstawione w porządku czasowym, bowiem ich rozwój nie jest wyłącznie sekwencyjny, lecz częściowo równoczesny. Jest to dowodem, charakterystycznej dla nauk społecznych, wielości paradygmatów nauki o zarządzaniu projektami. 


\section{Podsumowanie}

W iedza o zarządzaniu projektami, po kilkudziesięciu latach rozwoju, osiągnęła stan skłaniający do refleksji dotyczącej jej osiągnięć, deficytów i nowych wyzwań naukowych. Szczególne znaczenie w tej fazie rozwoju ma oparta na ogólnie akceptowanych podstawach metodologicznych ocena stosowanych podejść badawczych i wynikających z nich paradygmatów. Świadomość możliwości i ograniczeń tych podejść i związanych z nimi wymagań pozwala na uzyskiwanie wartościowych wyników i ich prawidłową interpretację.

Analiza literatury przedmiotu prowadzi do wyodrębnienia czterech podejść badawczych stosowanych w zarządzaniu projektami: operacyjnego, procesowego, organizacyjnego i zrównoważonego. Podejścia te posiadają wyraźną odrębność, zarówno w zakresie inspiracji praktycznych i teoretycznych, jak i założeń: ontologicznych, terminologicznych, aksjologicznych i epistemologicznych. Charakterystyka tych podejść przedstawiona została w artykule. Podejścia te kształtowały się $\mathrm{w}$ różnych okresach, uzyskując upowszechnienie i stając się paradygmatami. Efektem zastosowania tych podejść jest znaczący dorobek teoretyczny i praktyczny zarządzania projektami.

Refleksja nad podstawami metodologicznymi i analiza dorobku powinny stale towarzyszyć nauce o zarządzaniu projektami i być pogłębiane w dalszych badaniach, bowiem stanowią one podstawę do jej właściwego rozwoju.

prof. dr hab. Michał Trocki

Szkoła Główna Handlowa w Warszawie

Kolegium Zarządzania i Finansów

ORCID: 0000-0002-0082-489X

e-mail: michal@trocki.info

\section{Bibliografia}

[1] Abbasi A., Jaafari A. (2018), Evolution of Project Management as a Scientific Discipline, „Data and Information Management”, Vol. 2, No. 2, pp. 91-102.

[2] Apanowicz J. (2005), Metodologiczne uwarunkowania pracy naukowej, Difin, Warszawa.

[3] Blackburn S. (2004), Oksfordzki słownik filozoficzny, Książka i Wiedza, Warszawa.

[4] Bombała B. (2018), Kwestia paradygmatu w naukach o zarzadzaniu a Kenetha D. Stranga model badania organizacji, „Zagadnienia Naukoznawstwa”, Nr 1-4, s. 3-21.

[5] Bryman A., Bell E. (2007), Business Research Method, Oxford University Press, Oxford.

[6] Chiu Y.C. (2010), An Introduction to the History of Project Management: From the Earliest Times to A.D.1900, Eburon Academic Publishers, Delft.

[7] Cyfert S., Dyduch W., Latusek-Jurczak D., Niemczyk J., Sopińska A. (2014), Subdyscypliny w naukach o zarzadzaniu - logika wyodrębnienia, identyfikacja modelu koncepcyjnego oraz zawartość tematyczna, „Organizacja i Kierowanie", Nr 1(161), s. 37-49.

[8] Frankfort-Nachmias C., Nachmias D. (2001), Metody badawcze w naukach społecznych, Zysk i S-ka, Poznań.

[9] ISO 21500 (2012) Guidance on Project Management.

[10] Klincewicz K. (red.), (2016), Zarzadzanie, organizacje $i$ organizowanie - przeglad perspektyw teoretycznych, Wydawnictwo Naukowe Wydziału Zarządzania Uniwersytetu Warszawskiego, Warszawa.

[11] Krzyżanowski L. (1985), Podstawy nauki zarzadzania, PWN, Warszawa.

[12] Kuhn T.S. (2011), Struktura rewolucji naukowych, Wydawnictwo Aletheia, Warszawa.

[13] Lundin R.A. (2016), Project Society: Paths and Challenges, „Project Management Journal”, Vol. 47, No. 4, pp. 7-15.

[14] Morgan D.L. (2007), Paradigms Lost and Pragmatism Regained: Methodological Implications of Combining Qualitative and Quantitative Methods, „Journal of Mixed Methods Research", Vol. 1, No. 1, pp. 48-76.

[15] Nieto-Rodriguez A. (2012), The Focused Organizations, Gower, London.

[16] Packendorff J., Lindgren M. (2014), Projectification and its Consequences: Narrow and Broad Conceptualisations, "South African Journal of Economic and Management Sciences", Special Issue 17, pp. 7-21.

[17] Pszczołowski T. (1978), Mała encyklopedia prakseologii i teorii organizacji, Ossolineum, Wrocław.

[18] Seymour T., Hussein S. (2014), The History of Project Management, „International Journal of Management \& Information Systems", Vol. 18, No. 4, pp. 233-240.

[19] Stachak S. (1997), Wstęp do metodologii nauk ekonomicznych, Książka i Wiedza, Warszawa.

[20] Strang K.D. (ed.), (2015), The Palgrave Handbook of Research Design in Business and Management, Palgrave Macmillan, New York.

[21] Sułkowski Ł. (2016), Teorie, paradygmaty, metafory i ideologie zarzadzania - kontrowersje wokót współczesnego dyskursu organizacji i zarządzania, Prace Naukowe Uniwersytetu Ekonomicznego we Wrocławiu, Nr 422, s. 131-143.

[22] Tharenau P., Donohue R., Cooper B. (2007), Management Research Methods, Cambridge University Press, Cambridge.

\section{Research Approaches to Project Management - Genesis and Evolution}

\section{Summary}

Project management is a field of management, finding practical applications in all the areas of human activity, with distinctly shaped individuality. The development of project management is accompanied, though with delays, by the development of project management science. Previous achievements and experience in this field lead to systematisation of scientific activities in project management and determination of its main approaches and paradigms. The article presents the basics of such 
systematisation based on the analysis of methodological, general and management concepts as well as its results in the form of four research approaches: operational, process, organizational and sustainable. Systematisation has been made on the basis of an assessment and critical analysis of the subject literature, research results and methodological studies and proven good practices. Systematisation, indicating the possibilities and limitations of individual approaches, is meant to improve the methodological quality of research conducted in the field of project management.

\section{Keywords}

project management, research approaches, project management paradigms 